\title{
Slovak Retail Facilities in the Postwar Period
}

\author{
ANDRÁŠ Milan ${ }^{1, a^{*}}$ \\ ${ }^{1}$ Slovak University of Technology in Bratislava, Faculty of Architecture, Institute of Civic Structures \\ Námestie slobody 19, 81245 Bratislava, Slovak Republic \\ aandras@fa.stuba.sk
}

\begin{abstract}
Keywords: retail unit, historicist formalism, wide variety store, symbology of shapes, cubic expression, socialist realism, cubic locution, postmodern view, cooperative store, consumers cooperative, rural, market, supermarket, hypermarket.
\end{abstract}

\begin{abstract}
Retail units built in Slovakia after the war have continued in the tradition of the functionalist pre-war production, where the emphasis was placed on rational operation. Their solutions: disposition-spatial, material-construction and operational were determined by socioeconomic and political conditions of a totalitarian regime. Directional management of construction has been focused on building-up sale units in central urban areas, in areas of newly-formed residential dwellings and conditions of rural settlements. Insufficient design capacities led to the creation of typified designs. Sterile cubic solutions conditioned by the building-material base of society were reflected in the austere architectural embodiment. The transformation process of the nineties significantly affected the overall retail structure. The possibility of entrepreneurship and free pricing encouraged vendors to build large numbers of different small-scale devices. Globalization tendencies with an internationalization of trade and the free movement of capital caused by the turn of the century led to the building of major shopping centers with super and hypermarkets. The building was focused initially to the remote large settlements and later to wider centers of towns. Architecture of modern suburban retail buildings is marked by utility of function, low-floor construction, and high volume mass. By typological and material-constructional solution and by austere architectural expressions we have the adjective "ephemeral".
\end{abstract}

\section{Introduction}

Commercial buildings among the public buildings are ranked among the most with utilitarian function. They are built around the world in order to achieve the greatest gain at the lowest possible cost. In Slovakia, led by the idea of utility, many traders in the first half of the 20th century built up meaningful business establishments with austere modernist expression.

This is documented, for example, by the store the Danube and the former Bat'a store in Bratislava. Business units that emerged in the post-war period were following the pre-war functionalist tradition of design [1], where the emphasis was on rational operation. Their architectural design was determined in the 20th century by socio-economic and political conditions of a totalitarian regime. In view of the above conditions it can be divided into:

-objects built in central urban areas,

-business establishments located in newly created residential units,

-buildings built in rural settlements.

By directing construction activities to restore war-damaged buildings and housing, commercial establishments in the post-war period relegated to the background. Commercial facilities were built only in emergency cases as part of residential buildings.

\section{Buildings Built in Central Urban Areas}

The construction of commercial buildings in central areas of cities began at the end of the 50s. Typically they were commercial facilities whose architecture was marked by historicist formalism and efforts to adapt to the ambient constructions [2], as in the case of store Rozvoj in Prešov. 
Under the influence of foreign spectacular realizations in the $60 \mathrm{~s}$, construction was built in city centres on the land of demolished historical buildings, with a wide variety stores of large construction volumes without respect to adjacent objects. They were located in the focal positions, typically near intersections of main streets, or on routes "center - station of passenger transport".

Designing of the overall shape was based on contrasting mass structure, horizontals and verticals. Gradually there was created a symbology of shapes of stores, consisting of undercutted glazed entrance floor, with smooth external walls of the upper floors, combined with glazed continuous area along the entire height of enclosing structures [2]. Bulky cubic shapes with austere façade combined with large glass walls and flat roofs starkly contrasted with adjacent historical valuable buildings. Examples of this period are stores in Košice (architect R. Žertová), Trenčín (architect J.Melichar) in Bratislava (architect I.Matušík), as well as in other cities. This trend continued partly through to the eighties of the last century.

The initial noble simplicity and headedness of this new approach began to fade over time. Whole society and professional criticism meant that already in the seventies and even eighties, some makers had begun to implement a more sensitive approach to the designing stores [3] in order to make optimal integration of new constructions into the urban fabric. Among many good examples we can mention a store Jednota in Trnava (architect L.Lýsek), Dom Odievania situated in Námestie SNP in Bratislava (arch.J.Bahna), store Prior in Prešov (F.Kalesný architects and F.Minárik), or emporium Vtáčnik in Prievidza (P.Valach architects and I. Kepko).

\section{Business Establishments in the Newly Created Housing Units}

In the newly created residential areas were initially built commercial establishments as part of residential buildings located in the entrance level. Despite the negativity resulting from the philosophy of socialist realism enriched monotonous building block and in many cases, they got the city-forming character, for example Miletičová street in Bratislava (architect K.Paluš) or at the Pavlovičovo námestie in Prešov [2].

Extensive construction of new residential units in the second half of 50s, industrialized building production, and a creative functionalist approach allocated commercial establishments into solitary, square buildings with large-size glass walls and flat roofs. Striving for efficiency of circulation of vending units led investors (state) to the pooling of commercial establishments in focal positions estates, their assembly on a busy pedestrian moves. That is how the new typology of mall with single-storey or two-storey buildings was created. Although the concept was austere, without any deeper philosophical ideas with the absence of the formation of urban space. Because of the territorial integration of business functions, there was a richer supply of services, making it more attractive to visitors.

Shops protruded into the front of residentail buildings were adopted in a positive way, for example, Račianska street in Bratislava (authors: Š.Svetko, V.Houdek and O.Dukát), shopping malls Lunik I, II in Košice (architects: E.Kramár and J. Šprlák) [4]. From a series of standard examples exempts an atypical solution of shopping mall Slimák with circular floor plan located on Kukučínova street in Bratislava (architect I.Matušík). The tendency of solo buildings, constructed under the dictates of large-scale production with cubic expression, without aesthetic esprit, persisted until the end of the eighties. These were attempts to revive them, for example, the design of Ivana Marco, whose solutions in Dolné hony or in Záhumenice in Bratislava also defied the former universe. Neither did he succeed, due to a misunderstanding of the investor, hard constraints by the supplier, the absence of other features in the restricted area, to bring these centers shape of streets or respectively squares.

Failure to create socio-generated shopping centers in the late seventies efforts to repositioning of commercial establishments into the ground floor of residential buildings with the greatest application of the construction of the largest housing estate in Central Europe "Petržalka". Undersized sale areas [5] in new parts of the town necessitated the construction of additional capacities mostly whole settlement importance. One of the buildings is the store Ružinov in Bratislava. Architect J. Bahna tried to apply postmodern view into the overall concept of the object. 
Unconventional shape enriched solution has become a landmark between modernist and postmodernist conception of architecture. Happy transformation of basic themes of a new world's flow to our current conditions opened the way of looking at art, especially to the younger generation, that went this new way until the beginning of the transformation to the market economy system.

\section{Commercial Facilities in Rural Settlements}

Political and economic changes after February 1948 had a strong reflection in architecture and rural retail establishments. While the city was defined for the retail sector to governments, to villages was given the task of developing retail establishments of cooperative trade through consumers cooperative called "Jednota" [6]. The building-up began in late 50s. To ensure the building design was created central design organization, that was responsible for delivering projects for all villages. Insufficient capacities led to the creation of typified designs and their subsequent application. Sterile cubic solutions with large glass windows, flat roof raised rural regional conflict with modern universal. Siting and constructing of stores and shopping centers in the rural environment, without analyzing the local architectural specifics, transformation of modernist shapepoor solutions with urban housing scale to the picturesque small built-up areas inflicted great cultural and historical damage to the overall architectural expression of villages. Dissatisfaction with the estate prompted, in the late $70 \mathrm{~s}$, some users to order atypical projects with the requirement of respect for a particular environment [4]. Completed objects of the mall in Spišské Podhradie (architect Bandžák), a shopping mall in Moravany nad Váhom (architects: Dobrotka, Remenár, Augustín, Kašický) or object of grocery and municipal office in Dolná Lehota (architect D.Čupka) confirmed, that creative approach may be beneficial for the village environment. Unfortunately, in Slovakia were built very few positive evaluated implementations.

\section{Retail Establishments in the Period of Transition to a Market Economy}

The transformation process of the nineties significantly affected the overall retail structure. Privatization, free pricing, the possibility of entrepreneurship, but also the decrease of purchasing power of the population have resulted in the building of small-scale boutiques, kiosks, small business establishments in the spirit of post-modernism and historicism in cities and also in villages. In addition, in the cities were becoming more and more popular marketplaces. One remarkable example is the market in Komárno, that was created in the context of the Hungarian regional architecture. The last decade of the 20th century is characterized by the absence of building largescale commercial facilities in central urban areas. The only exception is the capital city, where foreign capital entered the central areas and reconstructed or built new commercial buildings whose shape-mass solution, facades, colorful treatise respects the urban environment, such as business center in Bratislava on Bottova street by Talašovci architects, objects City Point and City Centre on Obchodná street, Bratislava. Peripheries are witnessing the emergence of new typologies of retail, such as shops of sanitary ware (Jopa in Bratislava), furniture (Jopa Centre in Banská Bystrica, arch. Š. Moravčík), car sales, petrol stations, whose solutions are fresh, corresponding with international trends and recover our sterile environment.

The capital significantly reflects the tendency of building large shopping centers with supermarkets and hypermarkets in the boundary sites of towns in close connection to the transportation system. Architecture of retail establishments Tesco in Košice, Nitra, Ikea in Bratislava, Baumax in Bratislava, Prešov, Banská Bystrica, Carrefour in Petržalka or shopping center Soravia on Rožňavská street is marked by utility of function, austerity of architectural style, low-floor buildings, large volumes masses without proper interpretation. This architecture with its typology, material and design and its austere architectural expression has acquired the attribute "ephemeral" [7]. 


\section{Summary}

Based on international experience, it is expected that the trend of building suburban shopping centers will continue in the coming years. In their design will be increasingly significant aspect prefer enviromental solutions architectural concept [8]. The merits of such routing is supported by real facts-building is now the largest consumer of energy (about $40 \%$ of the total energy consumption for heating, air conditioning, lighting). The solution will be effective utilization of advanced technical technologies. These allow saving energy, produce, accumulate, absorb and recover. Photovoltaic systems and the pursuit of effective use of solar energy creates new opportunities for composite rendering of commercial buildings. New alternatives in architectural design allow time to crystallize a separate typological species with specific morphological solution that have crystallized over time separate typological species with specific morphological solution, a special status in the urban organism, with which we have become familiar.

Successful examples of commercial facilities built in recent years are a platform for optimism and a belief that new commercial buildings architectural solutions are imaginative, unrepeatable, to respond to trends in the world, while respecting the surrounding environment.

\section{References}

[1] M. Kusý, Architecture in Slovakia 1945-1975, Pallas Bratislava, printers SNP Martin, 1976, pp. 242.

[2] J. Krivošová, E. Lukáčová, Conversion of contemporary architecture in Slovakia, ALFA Bratislava, 1990, ISBN 80-05-00600-4, pp. 200.

[3] M. Dulla, H. Moravčíková, Architecture of Slovakia in the 20th century, Slovart Bratislava 2002, ISBN 8071456845, pp. 511.

[4] M. Dulla, J.Krcho, J. Krivošová, M. Kvasnicová, H. Moravčíková, J. Pohaničová, J. Rajtár, D. Šoltésová, Architecture in Slovakia - a brief history, Slovart Bratislava 2005, ISBN 80-8085-079-8, pp. 183.

[5] F. Križan, Globalization of retailing: definition of fundamental processes and their analysis in the retail geography of Slovakia. In:http://www.regionalnageografia.sk/upload/personal/Kri\%C5\%BEan,\%20F.\%20(2009).pdf, 20.07.2014.

[6] Z. Szczyrba, Geography trade: focusing on current trends in retail, UP Olomouc, 2006, ISBN 80-244-1453-8. pp. 90.

[7] H. Moravčíková, M. Topolčanská, P. Szalay, M. Dulla, S. Ščepánová, S. Toscherová, K. Haberlandová, Bratislava atlas of mass housing, Bratislava, Slovart 2011, ISBN 978-80-556-0478-7

[8] E. Oravcová, Photovoltaics - a compositional tool for creation of architectural concept/ Civil buildings. In: Energo Concepts IV. Designing buildings: Proceedings of Scientific Seminar, Bratislava, June 2007. Bratislava: STU, 2007. - ISBN 978-80-227-2765-5. - pp. 24-33. 